\title{
Up in Smoke? The Impact of Smog on Risk Perception and Satisfaction of International Tourists in Beijing
}

\author{
JING LI ${ }^{1}$, PHILIP L. PEARCE ${ }^{2}$, ALASTAIR M. MORRISON ${ }^{3 *}$ and BIHU WU ${ }^{1}$ \\ ${ }^{1}$ College of Urban and Environmental Sciences, Peking University, Beijing, China \\ ${ }^{2}$ College of Business, Law \& Governance, James Cook University, Townsville, Australia \\ ${ }^{3}$ College of Health and Human Sciences, Purdue University, West Lafayette, IN USA
}

\begin{abstract}
This research explored the perceptions of on-site international tourists towards the smog in Beijing. A scale measuring the degree of tourists' concern about smog conditions was developed. The links among smog concern, risk perception, trip satisfaction and destination loyalty were tested with a structural equation model. Direct relationships were found for the hypothesized effects of smog concern on risk perception and satisfaction. Further, the influence of risk perception on reducing satisfaction as well as the role of satisfaction in forming revisit intention (loyalty) was identified. The broad concerns of this study are applicable across all key Chinese tourism cities visited by international tourists.
\end{abstract}

KEY WORDS Beijing; loyalty; risk perception; satisfaction; smog

\section{INTRODUCTION}

The topic of concern of this research is smog, and the destination of interest is Beijing, China. The present study investigated the attitudes and behaviours of international on-site tourists to the worrying issue of smog in China's capital. The work is embedded in previous theoretical and conceptual studies of risk and hazard perception. Social and natural disasters affecting tourism are widely reported in various media formats (Kozak et al., 2007). Tourism research concerning such disasters has become an important concern of tourism analysis (Reisinger \& Mavondo, 2005; Tan \& Tang, 2013). Previous studies have tended to explore attitudinal and behavioural patterns of people who plan to travel, thus concentrating on their decision-making processes. However, tourists' risk perception and in turn their moderating strategies may change according to different stages across the travel consumption sequence (Choi et al., 2012). Therefore, it is necessary to investigate tourists' risk perception in different travel stages including pre-travel decision making, on-site reactions and post-trip recollections (Mansfeld, 2006). By focusing on smog-a relatively persistent and somewhat predictable form of hazard - and accessing tourists' on-site views, the present study may illuminate the existing studies of tourist risk perception.

In the past two years, dangerous smog conditions have been experienced in most cities in China. Smog is a frequently visible, sometimes literally tangible, generic term for air pollution deriving from multiple human activities including but not limited to the burning of fossil fuels and industrial processes (Watts, 2010). The National Disaster Relief Department of China has listed smog as a natural disaster due to the rising numbers of deaths attributed directly

* Correspondence to: Alastair M. Morrison, College of Health and Human Sciences, Purdue University, West Lafayette, IN USA.

E-mail: alastair@purdue.edu to severe incidents of the problem. Further, the overall harmful effects of smog on human health justify public concern and research interest (Bickerstaff \& Walker, 1999; Semenza et al., 2008). According to Tasci and Boylu (2010), disasters (and smog can now be included in the list of disasters) exert immediate and continuing effects on tourist choices through affecting a destination's image. Such effects are dramatically enhanced when the topic of concern is frequently reported in mass media. The available statistical data show declines in inbound and domestic tourists visiting the worst smogaffected areas in China.

Beijing is the Chinese city with perhaps the most serious and widely publicized smog conditions. It is also one of China's most popular tourist destinations. The city and its region have been one of the hardest-hit locations in terms of the frequency of smog and the severity of fine particle matter in the atmosphere. However, there has been very limited research directly exploring the impact of smog on tourists. Tourists' decision-making, in terms of choosing this destination, and their travel experiences in smog-affected cities such as Beijing have not been considered. It is generally accepted that understanding tourists' concerns, including their anxiety about health and safety issues, are of paramount importance to travel destinations (Kozak et al., 2007; Law, 2006). Building on these concerns, this research analysed the views of international tourists travelling to Beijing.

The present research has three broad objectives:

1. To explore international tourists' overall and specific concerns with the issue of smog in Beijing;

2. To examine whether there are associations among key tourist attitudes and perceptions including smog concern, risk perception, tourist satisfaction and intention to return to Beijing.

3. To consider whether the relationships found for risk in other content areas also exist for smog. 
In meeting these objectives, the work seeks to provide conceptual linkages and explore theoretical connections among key influential variables rather than simply describing tourists' concern about smog. Additionally, the marketing and management consequences of this study and allied research are portrayed.

\section{LITERATURE REVIEW}

A consideration of several themed areas of literature provides a technical and theoretical preparation for the present study. The areas of linked interest are the measurement of and human responses to air pollution; the studies of risk and the theories in this field; and the appraisal of tourist loyalty towards the destinations they visit. In combination, these studies assist in formulating direct hypotheses for this study and beyond that purpose address some wider concerns and contexts for this research topic.

\section{Human perception of, attitudes towards and response to air pollution}

Public concern about the state of the environment has become a globalized phenomenon (Sudarmadi et al., 2001). The alarm has been driven by the degradation of living spaces caused by the increasing environmental effects of damaging human activities. In efforts to address environmental problems and public concerns, there is a widening recognition that many environmental problems need a marriage of research disciplines and efforts (Cupples, 2009; Hulme, 2008; Hunter, 2000). For the present interest in the topic of smog and its effects on tourists, their choices and experience, the basic measures of smog provide a starting point for the investigation.

Monitoring the actual level of air pollution is a first step adopted by natural scientists. Levels of particulate matter (PM) effectively indicate the level of severity of air pollution because PM affects the visibility of the atmosphere and induces a range of environmental and public health issues (Ianniello et al., 2011; Wang et al., 2001; Zhang et al., 2003). In practice, air pollution indices evolved from the total particle mass concentration to measures involving elaborated sub-indices of various particles, especially of small particles such as $\mathrm{PM}_{10}$ (particles with aerodynamic diameters less than $10 \mu \mathrm{m}$ ) and even $\mathrm{PM}_{2.5}$ (Cao et al., 2013).

For measuring actual pollution level or air quality, the Pollutant Standards Index (PSI) that is calculated from the levels of five main air pollutants $\left(\mathrm{PM}_{10}, \mathrm{O}_{3}, \mathrm{SO}_{2}, \mathrm{CO}\right.$ and $\mathrm{NO}_{2}$ ) has been used since 1976. In the last two decades, high levels of $\mathrm{PM}_{2.5}$ aroused a special alarm because particles indicated by this measure can readily penetrate human lungs and induce serious diseases (Rupp, 2009). Therefore, PSI has been revised into the Air Quality Index (AQI), which now considers such new sub-indices as breakpoints and 8-hour average concentrations of $\mathrm{PM}_{2.5}$ (Cheng et al., 2007). Specifically, AQI grades air quality with a value from 0 to 500 and rates air quality into six levels from good to hazardous. The AQI score is calculated by identifying the concentration of pollutants that exceed a base level according to the National Ambient Air Quality Standards (Qian et al., 2004). AQI was first implemented in 1999 and has completely replaced PSI in the USA. Although AQI is not used worldwide because of the expensive monitoring instruments required, a majority of Chinese cities have adopted it to report real-time air quality every two hours.

Public awareness of air pollution has received the most research attention. For example, most of those interviewed in Jakarta, Indonesia were aware of the harmful effects of air pollution on human health (Sudarmadi et al., 2001). Immigrants to the USA were shown to be aware of the adverse impacts of air pollution caused by industry and cars, and its extreme danger to the environment (Hunter, 2000). There is much evidence revealing how certain air pollution characteristics (type, amount, frequency and source), the related publicity and individual characteristics influence people's awareness of air pollution problems. For example, $35.5 \%$ of the general public, and $86 \%$ of a well-educated sub-sample, cited air pollution from automobiles as the source of environmental problems experienced in their neighbourhoods (Sudarmadi et al., 2001). Far fewer respondents acknowledged the air pollution from factories. Direct experience and personal perception play more important roles in determining individuals' awareness of poor air quality, compared with any external source of information (Bickerstaff \& Walker, 1999).

Perceived risks and concerns induced by air pollution, the topics of this research, have been studied in broad terms. Several studies have found that it is the direct exposure that plays the most important role in influencing citizens' perceived seriousness of air pollution. Mediating relationships affecting this exposure-perceived seriousness link include actual air quality (Wall, 1973), demographic variables (Johnson, 2002), social-economic status (Bickerstaff, 2004; Bickerstaff \& Walker, 2003) and urbanization of regions (Jacoby, 1972). For example, the air pollution risk perceptions of residents in Hamilton, Canada were the result of everyday life experiences, especially sensing the exposure through seeing, smelling, touching and even tasting air pollution, rather than being based on expert assessments (Wakefield et al., 2001). Such findings are congruent with the belief that everyday personal experience is important in providing evidence of environmental risk (Bickerstaff \& Walker, 2001). Additionally, long-term residents tend to exhibit denial or exaggerated perceptions compared with newcomers (Evans et al., 1982) because environmental issues are usually linked to home, work and social interaction settings (Bickerstaff \& Walker, 2001). Individuals' annoyance with air pollution is considered an effective measure of overall environmental quality, and some countries (e.g. Sweden) have incorporated it into national environmental monitoring (Jacquemin et al., 2007). Moreira (2008) classified air pollution as a "stealth" risk and found that both residents and tourists were concerned more about stealth than catastrophic risks. Fuchs and Reichel (2011), working in Israel, demonstrated that bad weather and natural disasters were specific factors exacerbating tourists' perceived risk. 


\section{Tourists' perception of risk and concern about natural disasters and health issues}

The concepts of risk perception and concern are both used in this study, and the differences between these terms require explanation. Risk perception is generally used in tourism studies, while concern seems to be employed less frequently. The concept of perceived risk refers to an individual's view of the uncertainty and potentially negative consequences arising from buying products or services, performing certain activities or choosing a lifestyle (Dowling \& Staelin, 1994; Reisinger \& Mavondo, 2005). Specifically, uncertainty incorporates objective uncertainty (inherent uncertainty in products; uncertain places and mode of purchasing) as well as subjective uncertainty (views of possible psychological consequences) (Cox, 1967). Concern is a concept introduced from environmental psychology to the tourism area (Baldassare \& Katz, 1992; Hopper \& Nielsen, 1991). Scholars focusing on environmental issues tend to treat concern as an evaluation about facts and topics (Sjöberg, 1989; Takala, 1991). The concept of concern is best understood by linking it to values (Fransson \& Gärling, 1999). Specifically, anthropocentric altruism and selfinterest are important values underlying environmental concern (Stern, 1992). Concern can exist without a specific appraisal of risk for engaging in a behaviour or travel trip.

It can be noted here that risk perception does include subjective connotations. The chief distinction lies in the consideration of objective uncertainties in the definitional approach to risk. Further, some of the subjective factors underlying risk perception are shaped by the tourist's former behaviours, previous travel experiences and prior knowledge (Reichel et al., 2007; Sharifpour et al., 2014). In addition, while the degree of risk perception represents a judgement about the possibility of the unexpected, concern addresses individual attitudes towards existing phenomenon or at least those very likely to occur. It is usually adopted when a study aims to explore human attitudes and evaluation about certain feared outcomes without estimating the chance of those end states eventuating. The consequence of this discussion for the present research lies in differentiating between concerns and perceived risk. The former will be treated as a values-based orientation to the smog problem and the latter as a combination of subjective appraisals and objective information, specifically relevant to intended behaviour.

Extensive studies have been carried out to explore the dimensions or categories of risk perception. Some components of perceived risk include issues relating to financial, physical, psychological and satisfaction consequences or outcomes. Natural disasters, health risks, terrorism and political instability have been of much interest in tourist risk perception research (Roehl \& Fesenmaier, 1992; Sönmez \& Graefe, 1998). Other types of risk have also been proposed such as risks induced by cultural differences and barriers (Lepp et al., 2011). Simpson and Siguaw (2008) proposed ten risk sub-categories specific to travel. They carried out a descriptive study in which they directly asked 2000 travellers about their perceived risks. These travel risks represented broad themes: for example, health and well-being and criminal harm were identified, and these dangers can be linked to the physical risks commonly utilized in the consumer management area. Risk categories play a crucial role in determining how risky a certain condition is perceived to be (Lepp \& Gibson, 2003), al though various factors also mediate the levels of travel risk perception, including tourists' characteristics (Carr, 2001; Fuchs \& Reichel, 2004; Reisinger \& Mavondo, 2005; Seddighi et al., 2001), travel motivations (Dolnicar, 2005) and tourist segments (Dolnicar, 2005; Fuchs \& Reichel, 2006; Williams \& Baláž, 2013) For example, based on a large-scale sample drawn from the UK population, Williams and Baláž (2013) found package tourists and backpackers ascribed identical importance to specific hazards, which was related to their varied but ultimately overall equivalent weightings of different risk tolerance and perceived manageability of the risks.

It is generally accepted that tourists and the tourism industry are vulnerable to natural disasters, health threats and security disorders (Cavlek, 2002; McKercher \& Chon, 2004; Richter, 2003). For example, Lopez-Valez and Bayas (2007) claimed that international travellers tend to bear the risk of contracting severe infectious diseases. They highlighted the importance of studies addressing tourists' knowledge, attitudes and prevention practices. Similarly, Genton and D'Acremont (2012) claimed that certain tourist groups, especially long-term travellers, backpackers and visiting friends and relatives (VFR) travellers, are specific market segments at risk of acquiring malaria. The adverse impact of natural disasters, as well as tourists' concern over perceived safety and health relevant risks, has been intensively studied (Cavlek, 2002; Sharifpour et al., 2014). Fuchs and Reichel (2011) found that first-time visitors tend to be concerned about human-induced risk, socio-psychological risk, food safety and weather risks, while most repeat tourists fear the risks related to financial loss, service quality challenges, natural disasters and car accidents. There is clear evidence that tourist demand is susceptible to concerns about security and health (Blake \& Sinclair, 2003). Tourists' travel patterns are liable to change due to their concerns over perceived risks (Wilks \& Page, 2003). Mao et al. (2010) described and interpreted the changes in tourist arrivals to Taiwan from Hong Kong, Japan and the USA due to the outbreak of SARS, employing the cusp catastrophe model. Their study also identified both the tourists' fear or risk perception and the SARS alert imposed by government as two factors leading to the sudden change in travel flows. Page et al. (2012) identified the significantly negative effect of swine flu and the global economic crisis in 2008-2009 on tourism demand in the UK. They also quantified an estimated loss of 1.6 million visitors because of swine flu and a 3.7 million due to the economic crisis by utilizing an econometric time-varying parameter (TVP) model.

Tourists' strategies in facing perceived risks have also interested tourism researchers. Pre-visit perceptions of potential risk affect people's travel decisions. Perceptions of different dimensions of risks lead potential tourists to emphasize specific information sources (Sharifpour et al., 2014). Potential travellers are also liable to change their plans and even withdraw from a destination when they do not perceive safety levels to be adequate (Kozak et al., 2007). Most tourists seek to reduce their exposure to risk (Lepp \& Gibson, 2003); 
for example, Goodrich (2002) identified 27 countries that US citizens would avoid because of the relatively high perceived risks. As a specific case, an earthquake did change the image of Nantou, Taiwan. The disaster made some people withdraw from travel or lower their ratings about Nantou because of the fear or perceived risk from the possibility of inescapable further difficulties (Huan et al., 2004). On a more minor scale, when exposed to consistent news coverage that linked hospitality and tourism settings with a local epidemic of bed bugs, tourists avoided the affected establishments (Liu \& Pennington-Gray, 2015). In general, it has been shown that a disposition to avoid uncertainty leads to less travel, shorter stays and lower probability of trips by independent travellers (Crotts, 2004).

There are implications from these studies for management. Word-of-mouth is believed to be effective in reducing anxiety about perceived risks (Qu et al., 2011). With respect to the adverse impact of perceived risks on tourism demand mentioned previously, ensuring the safety and health of tourists is critical to maintain inbound tourism (Wang, 2009). Building loyalty to tourism products or a certain destination among tourists is an effective approach to mitigating their risk perception (Moutinho, 2000). Similarly, Dolnicar (2015) has emphasized the value of tourism organizations marketing their destination more strongly to those known to be the most resilient travellers.

\section{Tourist satisfaction and destination loyalty}

The concepts of tourist satisfaction and destination loyalty are major themes in tourist behaviour and consumer research (for reviews, see Pearce, 2005, 2011; Ryan, 1995). Measuring the level and exploring the components of satisfaction and destination loyalty are important pursuits for tourism marketers because of their direct linkage with repeat business (Akama \& Kieti, 2003; Chen \& Gursoy, 2001; Rittichainuwat et al., 2002). Risk perception has been frequently identified as an influential factor in mediating satisfaction among tourists. Positive perceptions of health, safety and security enhance tourists' travel satisfaction (Tasci $\&$ Boylu, 2010). The inverse relationship between the level of perceived risk in travel shopping and tourists' satisfaction has also been found (Yüksel \& Yüksel, 2007). Loyalty is one basis for maintaining core numbers of tourist arrivals and revenue (Mao \& Zhang, 2012).

Loyalty is usually viewed as an outcome of the decisionmaking-consumption process (Jacoby \& Chestnut, 1978). It is generally believed that loyalty is crucial in understanding what consumers need and want and in guaranteeing repeat purchases and word-of-mouth recommendations (Chen \& Gursoy, 2001; Mao \& Zhang, 2012; Petrick, 2004). Research on destination marketing has explored the composition of loyalty and has revealed factors influencing loyalty. Tourists' intentions and likelihood to revisit, repurchasing, recommendations, as well as their perceived travel satisfaction, are the main elements constituting destination loyalty (Oppermann, 2000). The significant contribution of tourist satisfaction to establishing destination loyalty has been confirmed in several studies (Kozak \& Rimmington, 2000; Mao \& Zhang, 2012; Yoon \& Uysal, 2005).
A number of theoretical formulations and an array of measures have been used to consider the determinants of and to assess satisfaction. The expectation-disconfirmation theory, equity theory, norm theory and perceived overall performance theory are the most frequently used theories to understand tourists' satisfaction (Yoon \& Uysal, 2005). The impacts of preconceived image on expectations and loyalty, as well as the effects of expectations and emotions on satisfaction levels among tourists, have been identified (del Bosque \& Martín, 2008). Similarly, tourists' moods play an important role in affecting experiential evaluations and satisfaction with tourism products (Huang et al., 2012). Quality also contributes to forming satisfaction, although it functions indirectly via perceived benefits acquisition (Nowacki, 2009). Tourism researchers often combine cognitive and affective perspectives when exploring satisfaction attitudes. Measures to assess satisfaction are varied and include direct measures and a range of creative techniques (Noe, 1999). As a small sample of this material, Eusébio and Vieira (2013) used a single item derived from the overall performance of a destination to measure satisfaction. Vitterso et al. (2000) adopted a three-item semantic differential type scale including boring-interesting, tiring-relaxing and irritating-pleasant as key items for assessment. For the purposes of the present study, these existing conceptual links between satisfaction and loyalty and the likely mediating role of risk influencing this relationship are of immediate interest. Additionally, the literature offers a wide variety of approaches to measuring these constructs. The relevant decisions on this measurement issue are documented in the Methodology section.

On the basis of the previous research, a conceptual framework was developed to depict the relationships among the selected variables, including smog concern, risk perception, trip satisfaction and loyalty intention. The directions specified for the following hypotheses are aligned with the major findings and research conclusions articulated in previous work and applied to the present context of tourists reacting to smog as a perceived risk to their travel. Six hypotheses proposing the direct relationships among the four variables were developed for testing via an empirical study:

H1: Concern with smog condition has a positive impact on the overall risk perception for the current trip.

H2: Concern with smog has negative influences on tourists' trip satisfaction.

H3: Risk perception has a negative impact on tourist satisfaction.

H4: Tourist satisfaction has a positive impact on destination loyalty.

H5: Concern with smog has a negative influence on destination loyalty.

H6: Risk perception has a negative impact on destination loyalty.

The pathways linking H1-H6 are presented in Figure 1. Additionally, the seventh and eighth hypotheses for this 


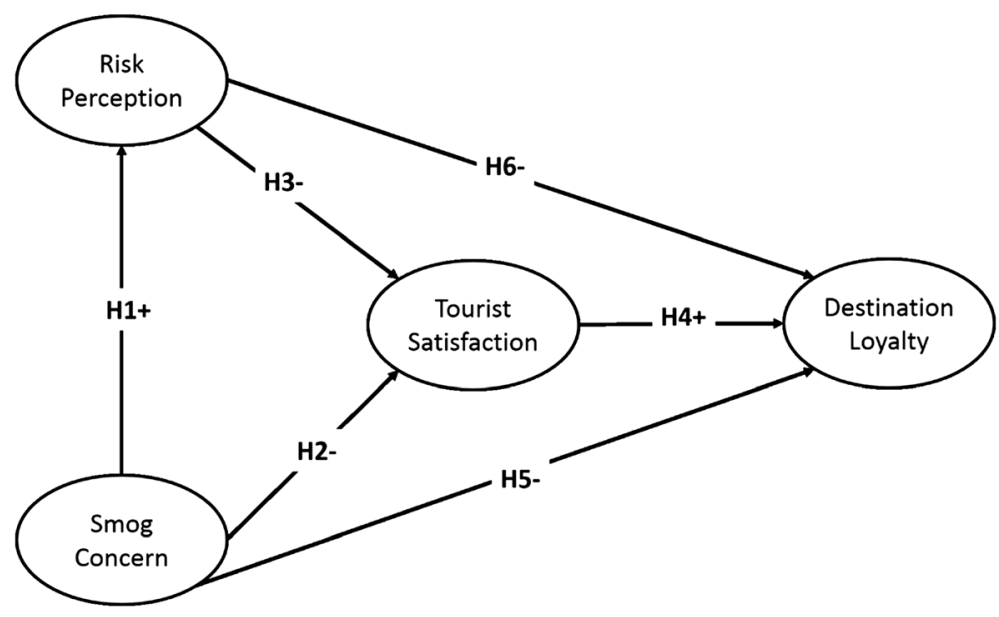

Figure 1. Hypothesized theoretical model

study consider the potential mediating factors between loyalty and other constructs. Thus,

H7: The correlation between risk perception and loyalty is mediated by other variables.

H8: The correlation between smog concern risk and loyalty is mediated by other variables.

\section{METHODOLOGY}

\section{Procedure and sample}

The research was conducted in three stages. First, in May 2014, brief face-to-face interviews were undertaken in Beijing with 26 international and 13 domestic tourists to reveal concerns about smog. The domestic tourists were interviewed to ensure no smog concerns or issues were overlooked in the exclusive focus on international tourist in this first set of interviews. The 39 interviewees were chosen randomly at Beijing Capital International Airport. All the respondents were asked three open-ended questions: 'were you aware of the smog conditions when staying in Beijing?', 'if yes, in what ways did the smog influence your travel?' and 'what did you do in response to smog conditions?' The most frequently mentioned and distinctive responses were selected for inclusion in the questionnaire for the second research stage.

The major survey was conducted in two stages. It was undertaken with international tourists to Beijing. A total of 150 questionnaires were distributed through face-to-face contact at the Summer Palace, one of the major tourist attractions in Beijing on 5 June 2014. One hundred and twenty-six usable questionnaires were collected. The questionnaire was developed based on the literature review, interviews with tourists from the first stage as well as consultation among the research team. It consisted of three parts: two multiple-choice questions asking whether tourists bought a mask and whether they checked AQI; scales measuring four constructs, including smog concern (SC), risk perception (RP), tourist satisfaction (TS) and future loyalty for returning to the location (FL), and a set of questions on respondents' demographics and behaviours as tourists. Minor adjustments to this questionnaire were made for the second phase of interviews, which were planned to specifically include varied smog-related conditions.

In the second phase of data collection, self-administrated questionnaires were distributed to 350 international tourists encountered at the Summer Palace in June, July and October of 2014. Three hundred and thirty-two fully completed questionnaires were collected and used for the analysis; the valid return rate was $94.9 \%$. Survey days were determined according to the AQI (Air Quality Index) in the morning. This selection of days was a purposeful attempt to include days with varying air quality. It was considered that collecting data from slightly different times of the year and across months would boost the applicability of the study and avoid the charge that only tourists' responses on high or low pollution days were sampled. The AQI values for the seven survey days (5 June, 9 June, 10 June, 3 July, 8 July, 10 October and 11 Oct 2014) did indeed vary and are shown in Figure 2.

In interpreting the AQI levels, under 100 is reasonably safe, over 150 is seen as dangerous and above 250 is rated as very unhealthy and hostile to human health.

\section{Instrument}

Two questions explored behaviours linked to the perception of smog concern (Hidalgo \& Hernandez, 2001). They were

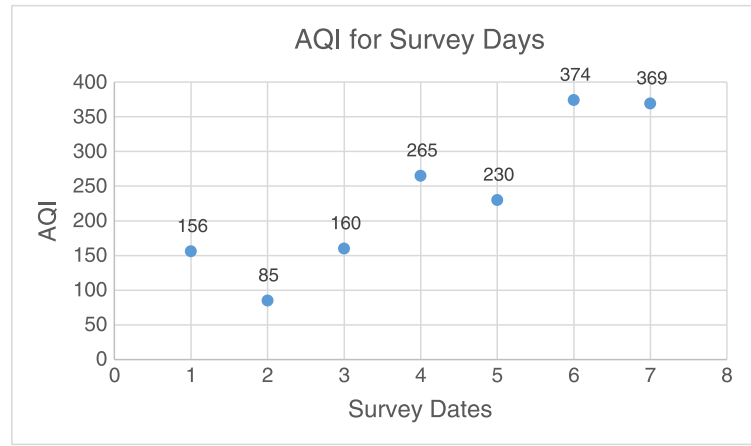

Source: http://air.castuduo.org/

Figure 2. Air Quality Index (AQI) for the survey period. Source: http://air.castuduo.org/. AQI values were recorded every two hours from 8: 00 to 22:00 hours, and the table shows the mean value. 
as follows: 'Did you buy a mask to protect yourself from the smog in Beijing?' and 'How often on average did you check PM2.5 or AQI during your stay in Beijing?' For the scales measuring SC, RP, TS and FL, respondents were asked to express their attitudes towards each statement using a seven-point Likert scale (from 1=strongly disagree to 7 =strongly agree). Questions about demographic information and tourist behaviours followed.

Smog concern was measured by eight items describing perceived attitudinal and behavioural responses to the conditions. The four statements were 'The Beijing smog is harmful to one's health even just with short-term exposure', 'The quality of my photos taken in Beijing was negatively affected by the smog', 'Beijing attractions are less enjoyable to visit when it is smoggy' and 'I shortened my trip to Beijing because of the smog.' These items were the most frequently mentioned by the interviewees in the first research stage and were supported by the literature. For example, a US tourist said 'my travel photos taken in Beijing look less attractive compared with others with blue sky, so I am I am hesitant to post them on Facebook.' A UK family said it was a pity that they could hardly see anything when they climbed the Great Wall because it was so smoggy. Two other items: 'I was concerned with the smog when planning the trip to Beijing' and 'the trip to Beijing was more influenced by the smog than what I thought before my arrival' were included. The negative emotional effects of air pollution were identified in previous research so the statement 'the smog has negatively influenced my emotions while in Beijing' was incorporated. One item to capture an overall attitude was as follows: 'the smog in Beijing has spoiled the quality of my trip to the city.' These measures of concern follow the distinction made in the literature review differentiating the constructs of concern and risk.

Tourists' risk perception was assessed by 11 items. Eight components of perceived risk (equipment, financial, physical, psychological, satisfaction, social, time and political risk) identified by previous literature (Roehl \& Fesenmaier, 1992; Sönmez \& Graefe, 1998) were represented by the statements: 'I may encounter mechanical and equipment problems on the trip to Beijing', 'the trip to Beijing does not provide value for the money spent', 'traveling to Beijing may result in physical danger, injury and sickness', 'traveling to Beijing will not reflect my personality or self-image', 'traveling to Beijing does not provide personal satisfaction', 'traveling to Beijing will affect others' opinion of me', 'traveling to Beijing takes too much time or it is a waste of time' and 'I may become involved in the political turmoil of China/Beijing during my trip.' The three statements 'the cultural difference may make me get into trouble', 'the communication barriers may make me get into trouble' and 'I am afraid of the strange food in Beijing' representing cultural differences and barriers from Lepp et al. (2011) were also included.

Tourist satisfaction was gauged by four items including one relevant to overall satisfaction and the other three regarding essential satisfaction components adopted from Oliver (1997). Future loyalty was measured on two sub-dimensions including intention to revisit and willingness to recommend (Bigné \& Andreu, 2004; del Bosque \& Martín, 2008; Yoon \& Uysal, 2005).

\section{Data analysis}

The first sample of 126 valid international responses collected in the first phase of the study was subject to reliability and validity examination using SPSS 20.0 software (IBM, Chicago, Illinois, USA). The internal consistency of each of the four constructs was assessed by Cronbach's alpha, and the predictive validity of individual items was evaluated by correlation analysis (Pearson correlation test) as well as discrimination analysis (independent-sample $T$-test). Then, the integrated sample of 458 international respondents, consisting of data collected in both the phases of the survey, were included in a confirmatory factor analysis (CFA) using AMOS 20.0 software (Amos Development Corporation/ IBM, Chicago, Illinois, USA) to test composition reliability and discriminant validity of the measurement model. Finally, a structural path model was run with the integrated sample by performing Bootstrap, with 5000 bootstrap samples and a $95 \%$ confidence level.

\section{RESEARCH RESULTS AND FINDINGS}

\section{Characteristics of international tourists}

The respondents' origins covered 35 countries (Table 1). The largest group was from the USA $(29.7 \%)$, followed by the UK, Germany, Canada and Australia. The USA accounted for $42.5 \%$ and Europe for $41 \%$.

There was an even distribution of genders (Table 2). Those aged between 25 and 44 years represented $42.8 \%$ of all respondents. Some $42.1 \%$ had earned university degrees. Approximately half (44.8\%) were employees, and a substantial proportion was students $(28.8 \%)$. Most (66.2\%) were visiting Beijing for the first time. The most frequent lengths of stay in Beijing were four to six nights (40.8\%) or seven nights or longer $(32.1 \%)$. Just over one quarter of the sample $(26.6 \%)$ had stayed for one, two or three nights. Some $71 \%$ mentioned sightseeing as one of their motivations; others stated leisure $(41.9 \%)$ and culture $(39.0 \%)$.

Almost $20 \%$ bought a mask to protect themselves from the smog. A majority (64.8\%) had not checked AQIs for smog conditions during their stay. These findings may be explained by the more important role of direct and chronic exposure than external information sources (Bickerstaff \& Walker, 1999; 2001; Wakefield et al., 2001) in arousing people's awareness and negative attitudes towards air pollution.

Table 1. Countries of origin $(n=458)$

\begin{tabular}{|c|c|c|c|c|c|}
\hline Country & Frequency & Percentage & Country & Frequency & Percentage \\
\hline USA & 136 & 29.7 & Italy & 12 & 2.6 \\
\hline UK & 44 & 9.6 & Finland & 11 & 2.4 \\
\hline Germany & 40 & 8.7 & South Africa & 9 & 2.0 \\
\hline Canada & 30 & 6.5 & $\begin{array}{l}\text { New } \\
\text { Zealand }\end{array}$ & 8 & 1.7 \\
\hline Australia & 29 & 6.3 & $\begin{array}{l}\text { Other } \\
\text { Americas }\end{array}$ & 26 & 6.3 \\
\hline France & 23 & 5.0 & $\begin{array}{l}\text { Other } \\
\text { Europe }\end{array}$ & 58 & 12.7 \\
\hline India & 14 & 3.0 & Other Asia & 18 & 3.9 \\
\hline
\end{tabular}


Table 2. The main characteristics of the full sample of respondents $(n=458)$

\begin{tabular}{|c|c|c|c|c|c|}
\hline Characteristic & & Percentage $(\%)$ & Characteristic & & Percentage $(\%)$ \\
\hline \multirow[t]{2}{*}{ Gender } & Female & 48.3 & \multirow[t]{2}{*}{ Revisiting } & Yes & 33.8 \\
\hline & Male & 51.7 & & No & 66.2 \\
\hline \multirow[t]{5}{*}{ Age } & Less than 16 & 0.8 & \multirow{9}{*}{$\begin{array}{l}\text { Travel motivation(s) (one can } \\
\text { mention more than one of these) }\end{array}$} & Religious & 3.8 \\
\hline & $16-24$ & 28.8 & & Health & 1.2 \\
\hline & $25-44$ & 42.8 & & Sightseeing & 71.0 \\
\hline & $45-64$ & 23.1 & & Leisure & 41.9 \\
\hline & 65 and older & 4.4 & & VFR & 18.8 \\
\hline \multirow{5}{*}{ Education Level } & High school or lower & 12.7 & & Cultural & 39.0 \\
\hline & Technical/trade qualification & 17.7 & & Business & 13.4 \\
\hline & University degree & 42.1 & & Study & 1.8 \\
\hline & & & & Other & 0.6 \\
\hline & Postgraduate or higher & 27.5 & \multirow[t]{5}{*}{ Length of staying in Beijing } & Less than one day & 0.4 \\
\hline \multirow[t]{8}{*}{ Occupation } & Employee & 44.8 & & $1-3$ nights & 26.6 \\
\hline & Businessman(woman) & 14.2 & & 4-6 nights & 40.8 \\
\hline & or freelance & & & More than 7 nights & 32.1 \\
\hline & Student & 28.8 & & & \\
\hline & Housewife & 4.1 & \multirow[t]{2}{*}{ Mask ownership } & Yes & 19.9 \\
\hline & & & & No & 80.1 \\
\hline & Retired & 5.9 & \multirow[t]{2}{*}{ If have checked AQI } & Yes & 35.2 \\
\hline & Unemployed & 2.2 & & No & 64.8 \\
\hline
\end{tabular}

\section{Scale verification}

\section{Reliability and validity}

The reliability of each measurement and the overall scale were examined using Cronbach's alpha. The alpha values of the four constructs were 0.827 (SC), 0.85 (RP), 0.873 (TS) and 0.904 (FL) respectively, and the overall scale was 0.835 (Table 3). They all exceeded the minimum hurdle of 0.7 (Nunnally \& Bernstein, 1994), indicating acceptable internal consistency and verifying the reliability of the survey.
Based on the corrected item-total correlation values, two items of the risk perception scale (R1 and R3) were removed because the corrected item-total correlation (CITC) was lower than 0.4, and the alpha values for the RP construct rose after their deletion (Table 3).

The remaining items were included in the Pearson correlation analysis. The product-moment correlation coefficients between each item and total score of the measurement to which they belonged were all significant at the 0.01

Table 3. Reliability tests

\begin{tabular}{|c|c|c|c|c|c|}
\hline Constructs & Item & $\begin{array}{l}\text { Corrected item - } \\
\text { total correlation }\end{array}$ & $\begin{array}{l}\text { Cronbach' alpha of each } \\
\text { construct if item deleted }\end{array}$ & $\begin{array}{l}\text { Cronbach' alpha of } \\
\text { each construct }\end{array}$ & $\begin{array}{l}\text { Cronbach' alpha of } \\
\text { overall measurement }\end{array}$ \\
\hline \multirow[t]{8}{*}{ Smog concern } & SM1 & 0.406 & 0.826 & \multirow[t]{8}{*}{0.827} & \multirow[t]{19}{*}{0.835} \\
\hline & SM2 & 0.472 & 0.817 & & \\
\hline & SM3 & 0.756 & 0.777 & & \\
\hline & SM4 & 0.647 & 0.793 & & \\
\hline & SM5 & 0.584 & 0.802 & & \\
\hline & SM6 & 0.577 & 0.803 & & \\
\hline & SM7 & 0.479 & 0.816 & & \\
\hline & SM8 & 0.480 & 0.816 & & \\
\hline \multirow[t]{11}{*}{ Risk perception } & R1 & 0.355 & 0.851 & \multirow[t]{11}{*}{0.850} & \\
\hline & R2 & 0.614 & 0.831 & & \\
\hline & R3 & 0.317 & 0.854 & & \\
\hline & R4 & 0.522 & 0.838 & & \\
\hline & R5 & 0.665 & 0.827 & & \\
\hline & R6 & 0.599 & 0.832 & & \\
\hline & R7 & 0.468 & 0.842 & & \\
\hline & R8 & 0.610 & 0.831 & & \\
\hline & R9 & 0.583 & 0.833 & & \\
\hline & R10 & 0.484 & 0.841 & & \\
\hline & R11 & 0.683 & 0.825 & & \\
\hline \multirow[t]{4}{*}{ Tourist satisfaction } & SA1 & 0.690 & 0.853 & \multirow[t]{4}{*}{0.873} & \\
\hline & SA2 & 0.723 & 0.841 & & \\
\hline & SA3 & 0.751 & 0.830 & & \\
\hline & SA4 & 0.758 & 0.826 & & \\
\hline \multirow[t]{4}{*}{ Future loyalty } & L1 & 0.715 & 0.689 & \multirow[t]{4}{*}{0.904} & \\
\hline & L2 & 0.847 & 0.846 & & \\
\hline & L3 & 0.877 & 0.864 & & \\
\hline & L4 & 0.771 & 0.748 & & \\
\hline
\end{tabular}


confidence level (two-tailed) and exceeded the conventional critical value of 0.5 , verifying the coherence among items within each construct.

\section{Item discrimination}

The survey data set was subject to an independent-sample $T$-test to assess each item's discriminating ability. The highest smog-concern group included cases with total SC scores above 46 (the top 27\%); the lower score group with total scores lower than 31 (the bottom 27\%). Similarly, cases were recoded into two groups again based on total RP, TS and FL scores. The results of the $T$-test showed that two-tailed $T$ values for the 25 items remaining in the scale were significant at the 0.05 level. This establishes a 95\% confidence level that all items are capable of discriminating among the respondents.

\section{Measurement model}

Acceptable composite reliability (CR), average variance extracted (AVE) and discriminant validity were found through two rounds of CFA. In the first round, all 25 items passing the reliability and validity tests were included. Consequently, three items of SC measurement and three of RP measurement were deleted because of standard loading estimates lower than 0.6. The remaining 19 items were incorporated into the next round. The CFA result of the new measurement model present acceptable model-fit indices, including chi-square/degrees of freedom ratio $(\mathrm{CMIN} / \mathrm{DF})=3.06$, goodness of fit index $(\mathrm{GFI})$ $=0.908$, normed fit index $=0.923$, incremental fit index $=0.947$, comparative fit index $=0.946$ and root mean square error $=0.069$ (Browne \& Cudeck, 1993). Moreover, all the regression weights for every construct in the prediction of each relevant item were significant at the 0.001 level (two- tailed) (Table 4). The composite reliability was verified with the CR values for the four constructs all exceeding 0.7 , indicating that each latent variable had acceptable internal consistency (Hair et al., 2006: 94).

The convergent and discriminant validity were assessed by the constructs' AVE and the correlation coefficients between each pair of constructs (Babin et al., 2004) (Table 4). AVE values for all four constructs exceeded the desirable value of 0.5 . This was evidence that the latent construct accounted for a majority of the variance in its indicators on average, suggesting acceptable convergent validity (MacKenzie et al., 2011). The construct inter-correlation between any pair of constructs was less than 0.71 , indicating that the constructs had significantly less than half of their variance in common (MacKenzie et al., 2011). Discriminant validity was further examined by comparing the AVE value with the squared inter-correlation for each pair of constructs (MacKenzie et al., 2011). The AVE for each construct was greater than the squared correlations between it and any other construct, demonstrating that each construct was able to be reliably distinguished from the indicators of other constructs (Fornell \& Larcker, 1981).

\section{Descriptive analysis}

Based on the responses to the questions, 'Did you buy a mask to protect yourself from the smog in Beijing?' and 'How often on average did you check PM2.5 or AQI during your stay in Beijing?', it appeared that tourists were not extremely concerned with the smog conditions. Nevertheless, if we consider a score of 3.5 as approximately indifferent, Table 4 suggests that international tourists did have substantial worries, with scores ranging from 3.54 to 4.91 for five

Table 4. Confirmatory factor analysis

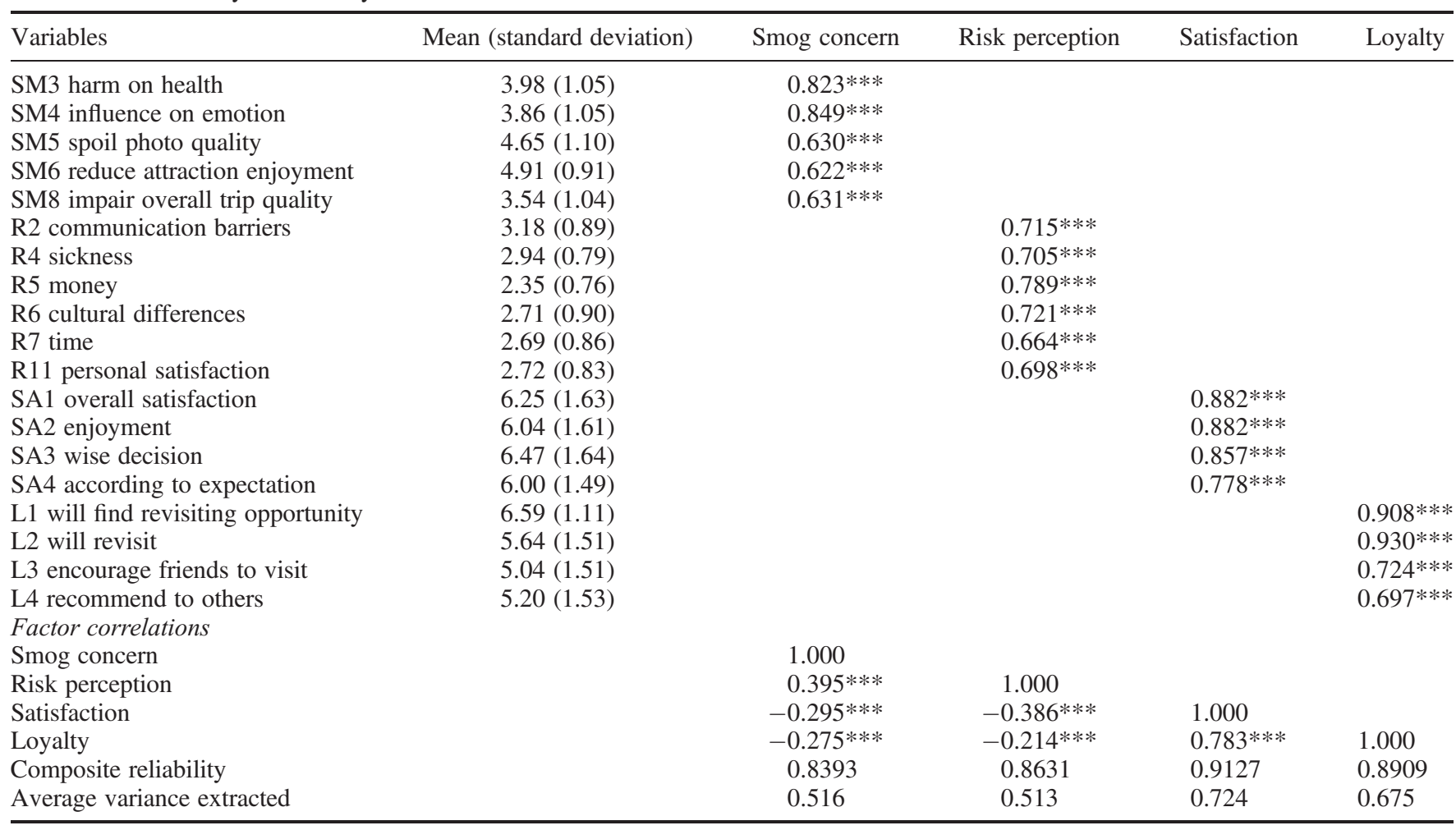

***Significant at 0.001 level. 
smog concern items. The negative influence of smog on the enjoyment of certain attractions concerned international tourists most, with a mean value of 4.91. Next in levels of concern were the adverse effects on photos (4.65), harm to health (3.98), emotions (3.86) and trip satisfaction (3.54). The modest concern about Beijing's air pollution may be explained by the short stays in smog-hit areas and a lack of knowledge of how to respond to smog conditions. These arguments were somewhat supported by additional respondent comments. For example, Respondent 6 commented: 'I would have checked if I knew the AQI before.' Respondent 18 could not speak Chinese, so he did not know how to check the AQI. Respondent 37 said she did not know about AQI and wished she did.

International tourists did not have high-risk perception levels for their travel in Beijing, with all the average RP scores lower than 3.5, effectively rating Beijing as a relatively safe destination. They perceived the greatest risk with communication barriers (3.18) followed by sickness (2.94). Slighter risk was perceived with personal satisfaction (2.72), cultural differences (2.71), time (2.69) and money (2.35). Moreover, respondents were satisfied with travelling to Beijing (6.25), appraised their travel decisions as wise (6.47), enjoyed their journeys (6.04) and found experiences matched their expectations (6.0). They expressed significant willingness to find opportunities to revisit (6.59), certainty of revisiting (5.64), a likelihood to recommend Beijing as a travel destination (5.2) and to encourage others to travel to Beijing (5.04).

\section{SEM path model}

\section{Data-model fitness}

The proposed path model was tested by a structural equation model with maximum likelihood by performing the bootstrap procedure. The structural equation model (SEM) model consisted of four latent constructs (SC, RP, TS and DL) and six paths linking them. The evaluation of GFI indices supported the model, indicating that the data fitted the model well. Specifically, the chi-square statistic was $\chi^{2}=442$ with degrees of freedom $=144$. It is generally accepted that a ratio of $\chi^{2}$ to degrees of freedom lower than five is acceptable. The $\mathrm{CMIN} / \mathrm{DF}=3.1$ verified the overall model fit. Other supplementary model-fit indices were considered because chisquare tests are sensitive to sample size ( $\mathrm{Hu} \&$ Bentler, 1995: 76-99). These indices indicated a good fit including $\mathrm{GFI}=0.905$, normed fit index $=0.921$, incremental fit index $=0.945$, comparative fit index $=0.945$, standardized root mean square residual $=0.0636$ and root mean square error =0.069 (Browne \& Cudeck, 1993; Hoelter, 1983; Ko \& Stewart, 2002; Nunkoo \& Ramkissoon, 2011). Therefore, the structural model approximated the observed data rather well (Figure 3).

\section{Model effects}

The results of SEM model tests supported H1, H2, H3 and $\mathrm{H} 4$, showing significant and direct causal relationships as proposed. H5, the direct (negative) impact of smog concern on loyalty intention, was not supported $(-0.059, p=0.19)$. H6, the direct (negative) relationship between risk perception and loyalty was not supported; however, there was a significant but opposite (positive) relationship. $\mathrm{H} 7$ and $\mathrm{H} 8$, which were concerned with the role of mediating variables affecting the relationship between smog concern and loyalty and perceived risk and loyalty, were supported.

The direct influence of tourists' concerns with smog conditions on risk perceptions during travel was indicated by a significant standardized estimate of 0.38 with standard error (S.E.) $=0.059, t=6.409$ and $p<0.001$. This confirmed the hypothesis that tourists will perceive greater risk if they have higher levels of concern about the smog conditions in Beijing. Similarly, the direct negative impact of smog concern on tourist satisfaction was verified by a standardized estimate of -0.20 (S.E. $=0.063, t=-3.689, p<0.001$ ), meaning that an increasing degree of tourists' concern over smog will result in lower satisfaction with Beijing as a destination. The negative relationship between the level of perceived risk and tourists' satisfaction was supported by a significant estimate of -0.31 $(\mathrm{S} . \mathrm{E} .=0.065, t=-5.523, p<0.001)$. Thus, the greater risk tourists perceived during travel, the less they feel satisfied with the trips. The positive relationship between tourist satisfaction and destination loyalty was strong with an estimate of 0.81 (S.E. $=0.044, \mathrm{t}=17.628, p<0.001)$.

Although the path model supported the direct relationship between risk perception and destination loyalty, it had a positive correlation instead of the hypothesised negative one, with a significant estimate of 0.12 (S.E. $=0.047, t=2.825$, $p=0.005)$. The path weights presented in the AMOS outcome figures only present direct effects between variables without considering indirect relationships. Actually, the results of the bootstrap test with the bias corrected method supported the existence of significant indirect relationship between risk perception and loyalty mediated by satisfaction. The two-tailed significance levels for standardized total effect was $\mathrm{P}_{\mathrm{R}-\mathrm{L}}=0.014<0.05$, confirming a significant total effect between risk perception and loyalty. The estimate of the standardized total-effect was $c_{\mathrm{R}-\mathrm{L}}=-0.133$, with S.E. $=$ 0.055 . Similarly, the direct relationship between risk perception and loyalty, and the relationships between risk perception and satisfaction, and satisfaction and loyalty, were found to be significant. The estimates of direct-effect coefficients were represented by the average estimates of standardized regression weights. They were $\mathrm{a}_{\mathrm{R}-\mathrm{SA}}=-0.314\left(\mathrm{P}_{\mathrm{R}-\mathrm{SA}}\right.$ $<0.001$, S.E. $=0.059), \mathrm{b}_{\mathrm{SA}-\mathrm{L}}=0.814\left(\mathrm{P}_{\mathrm{SA}-\mathrm{L}}<0.001\right.$, S.E. $=$ $0.036)$ and $c^{\prime}{ }_{R-L}=0.123\left(P_{R-L}<0.001\right.$, S.E. $\left.=0.049\right)$. Accordingly, the significant indirect impact of risk perception on destination loyalty mediated by satisfaction (Figure 4) is supported with an indirect effect weight of $\mathrm{a}_{\mathrm{R}-\mathrm{SA}}$ * $\mathrm{b}_{\mathrm{SA}-\mathrm{L}}=-0.314 * 0.814=-0.256$. The ratio of indirect effect to direct effect was $a_{\mathrm{R}-\mathrm{SA}} * \mathrm{~b}_{\mathrm{SA}-\mathrm{L}} / \mathrm{c}_{\mathrm{R}-\mathrm{L}}=-0.256 /-$ $0.133=1.92$, indicating that risk perception exerts an overall negative impact on destination loyalty jointly through indirect negative and direct positive effects, but is dominated by the indirect effect.

The direct relationship between smog concern and loyalty was rejected because of an insignificant estimate $(-0.05$, $p=0.19$, S.E. $=0.045)$. Nevertheless, an indirect correlation between smog concern and loyalty mediated jointly by risk perception and satisfaction was established. Two-tailed significance level for the standardized total effect was $\mathrm{P}_{\mathrm{SM}-\mathrm{L}}$ 


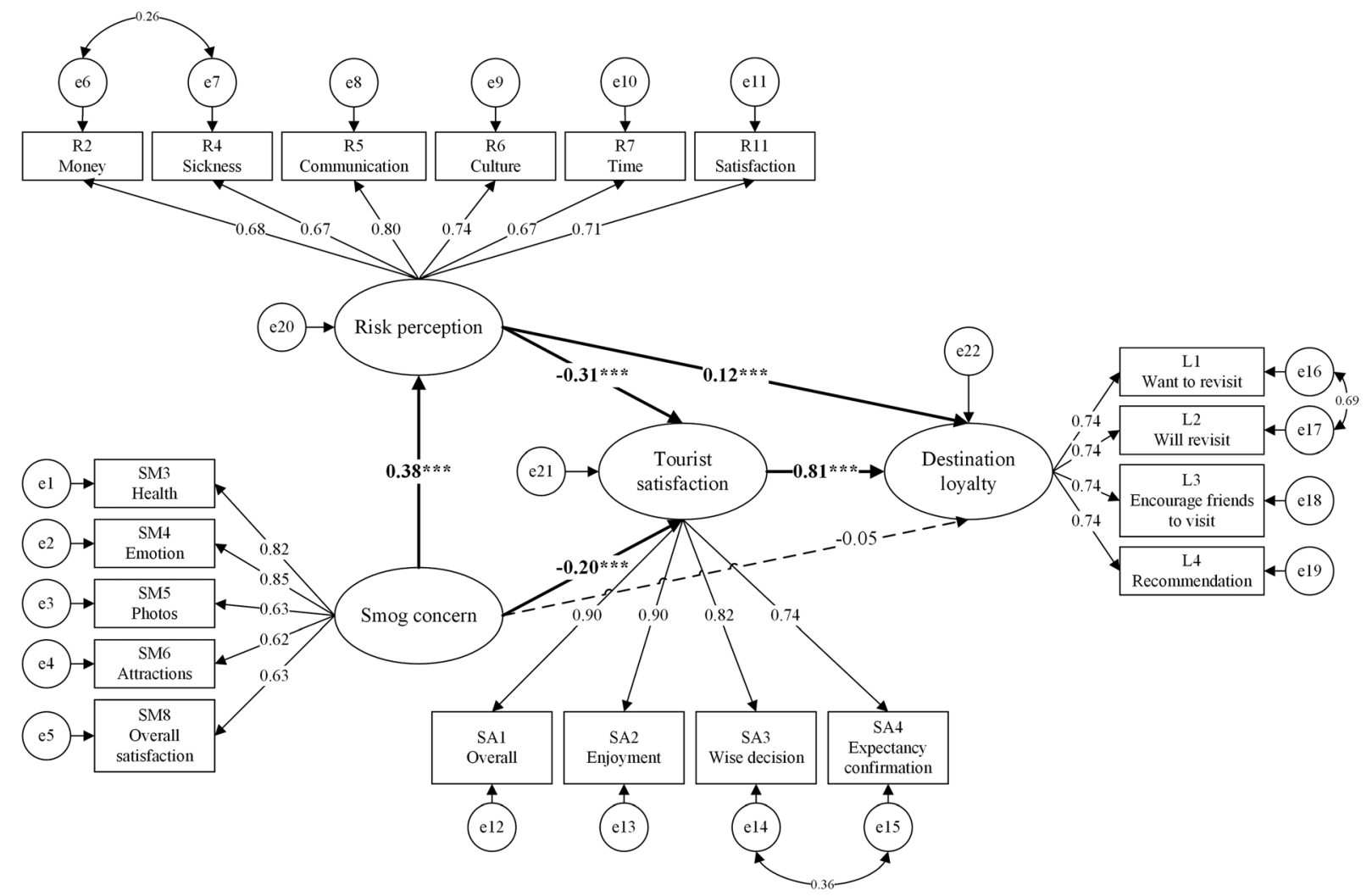

Figure 3. Standardized estimated hypothetical model

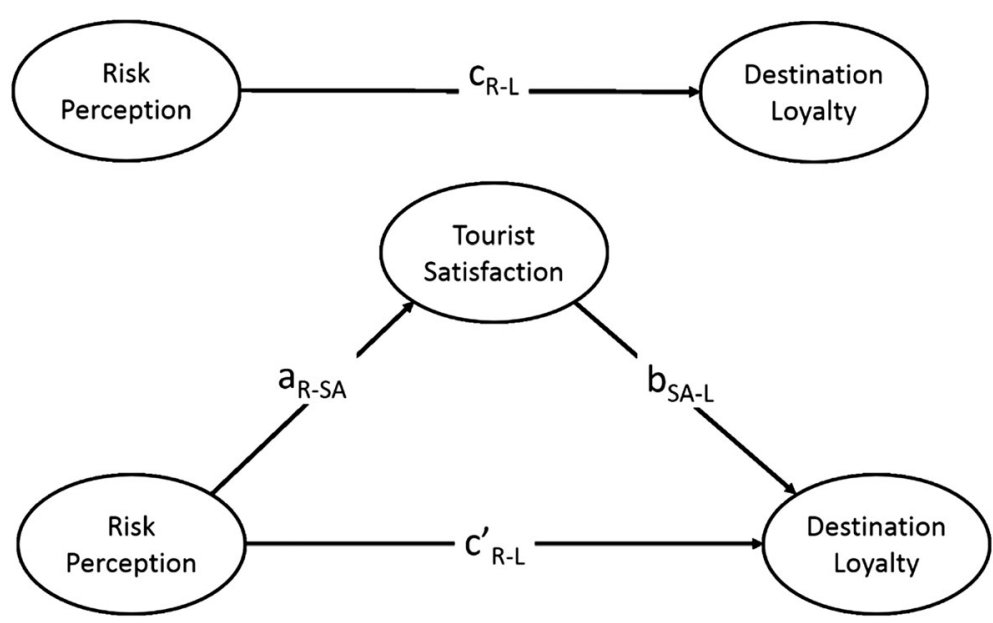

Figure 4. Mediating effect of satisfaction between risk perception and loyalty

$<0.001$, indicating a significant total correlation between smog concern and loyalty. The estimate of standardized total-effect was $\mathrm{c}_{\mathrm{SM}-\mathrm{L}}=-0.270($ S.E. $=0.056)$. The direct relationships between smog concern and loyalty, smog concern and risk perception, smog concern and satisfaction, risk perception and satisfaction, risk perception and loyalty, satisfaction and loyalty were found to be significant. The estimates of direct-effect coefficients were represented by the average estimates of standardized regression weight $\left(\mathrm{a}_{\mathrm{SM}-\mathrm{R}}=0.381\right.$ $\left(\mathrm{P}_{\mathrm{SM}-\mathrm{R}}<0.001, \quad\right.$ S.E. $\left.=0.052\right), \quad \mathrm{a}_{\mathrm{SM}-\mathrm{SA}}=-0.205$ $\left(\mathrm{P}_{\mathrm{SM}-\mathrm{SA}}=0.002, \quad\right.$ S.E. $\left.=0.063\right), \mathrm{a}_{\mathrm{R}-\mathrm{SA}}=-0.314\left(\mathrm{P}_{\mathrm{R}-\mathrm{SA}}\right.$ $<0.001$, S.E. $=0.059), b_{\mathrm{R}-\mathrm{L}}=0.123\left(\mathrm{P}_{\mathrm{R}-\mathrm{L}}=0.018\right.$, S.E. $=$
$0.049), b_{\mathrm{SA}-\mathrm{L}}=0.814\left(\mathrm{P}_{\mathrm{SA}-\mathrm{L}}<0.001\right.$, S.E. $\left.=0.036\right)$, and $c^{\prime}{ }_{\text {SM-L }}=-0.055\left(\mathrm{P}_{\mathrm{SM}-\mathrm{L}}=0.244, \mathrm{~S} . \mathrm{E} .=0.046\right)$. Accordingly, a significant indirect impact of smog concern on destination loyalty with multiple mediating effects of risk perception and satisfaction as mediators was found (Figure 5). The three indirect effect coefficients included $a_{\mathrm{SM}-\mathrm{R}} * \mathrm{~b}_{\mathrm{R}-\mathrm{L}}=0.381 * 0.123=$ $0.047, \mathrm{a}_{\mathrm{SM}-\mathrm{SA}} * \mathrm{~b}_{\mathrm{SA}-\mathrm{L}}=-0.205^{*} 0.814=-0.167$, and $\mathrm{a}_{\mathrm{SM}-\mathrm{R}} *$ $\mathrm{a}_{\mathrm{R}-\mathrm{SA}} * \mathrm{~b}_{\mathrm{SA}-\mathrm{L}}=0.381 *-0.314 * 0.814=-0.097$. The total indirect effect was $a_{S M-R} * b_{R-L}+a_{S M-S A} * b_{S A-L}+a_{S M-R} * a_{R-S A} *$ $b_{\text {SA-L }}=-0.217$. The ratio of indirect effect to total effect was $-0.217 /-0.270=0.837$. Therefore, smog concern exerts an inverse impact on destination loyalty through both direct and 


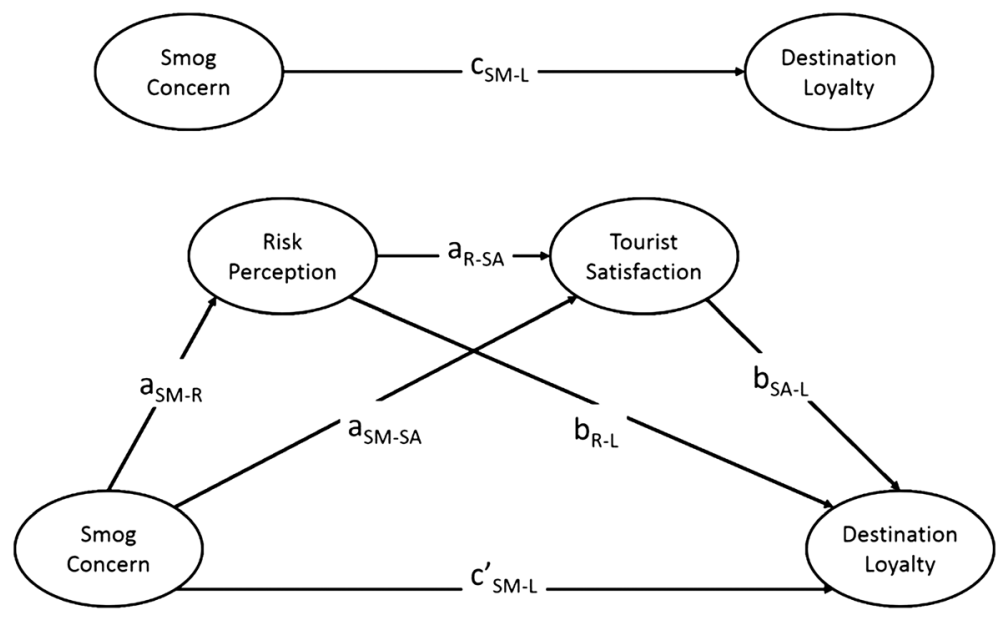

Figure 5. The indirect relationship between smog concern and loyalty

indirect effects, but this result was dominated by the indirect effect jointly mediated by risk perception and satisfaction.

\section{CONCLUSIONS AND IMPLICATIONS}

The research objectives were to identify international tourists' concerns about smog conditions in Beijing and to test a model of the relationships among smog concern, perceived risk, tourist satisfaction and future loyaltyFL. The model developed and tested in this study did support the major hypothesized links among key variables. More specifically, the results indicated that tourists were indeed somewhat concerned about the adverse effects of smog on their health, emotions, travel photos, overall trip quality and enjoyment of tourist attractions. The concern over smog affected perceived risk, satisfaction and loyalty. Specifically, the findings of the present work also revealed that smog will decrease tourists' satisfaction and degrade the destination image by deterring revisits and inhibiting positive word-of-mouth recommendations (cf. Sönmez \& Graefe, 1998). These kinds of consequences reach beyond the problems for the immediate set of tourists and their experiences of Beijing and can foreshadow losses for the tourism destination (Mao \& Zhang, 2012). Further, the present study considered only those who were visiting Beijing. It can also be suggested that there may be many others who have chosen to withdraw from a visit to Beijing because they too are concerned with the pollution and perceive higher levels of risk for the city. The findings may be linked to a parallel kind of study. Page et al. (2012) stated that the intensive media coverage on the number of swine flu cases within the UK contributed to a recorded drop in tourism volume.

Some limitations of the study that need to be addressed and overcome in future work include the point that the air conditions during tourists' entire trips to Beijing and their effects on perceptions and attitudes should have been considered in more fine-grained detail. The precise relationship between the conditions and respondents' views was not recorded on a specific daily basis. Nevertheless, the present work considered a range of smog-filled days and thus established an important baseline for such refined treatment of the topic. Additionally, the amount and nature of the information available on Beijing's smog condition in respondents' home places were not assessed. There are undoubtedly differences in the amount and quality of this kind of disaster and health-challenging information across the world. Arguably, such background information may affect expectations and tourists' on-site reactions. The smog concern measurement items were developed subjectively to some extent because there was no previous research focusing on how smog conditions affected tourists. The possibility of exploring the responses to specific market segments and in a wide range of Chinese cities also awaits further study. Nevertheless, some tourism industry and government level action can be drawn from these study findings.

Clearly, the presence of unacceptable levels of smog in Beijing is a reality, and from this study, there is contemporary evidence that the problem is recognized by international tourists with a range of negative consequences. Inaction however is an unacceptable path to follow. Importantly, all who are concerned with this problem would arguably reject a tourism approach, which only tried to find day-to-day tactics to manage tourists' experiences. The smog problems are indicative of fundamental pollution and sustainability issues rampant across China and troubling many cities in the country and beyond (Gore, 2013). The fundamental issue is that the various bodies need to do their best to cut emissions and reduce the causes of the 'smog disasters' (Watts, 2010). Businesses firms, governments and concerned citizens have roles to play in these control and change processes. It is recognized, however, that while this is desirable and essential, it is inherently a long-term process, although some other globally important tourism cities such as Singapore and London have accomplished much to improve their smog levels. A failure to respond in some immediate and direct way by tourism authorities could lead to a spiral of decline in Beijing tourism, with a loss of income for many businesses and diminishing international prestige for the government and civic authorities.

More immediate and pragmatic directions can also be identified. Quality information is one of the keys to shaping tourist behaviour, but sometimes, that information needs interpretation and context. Daily smog readings are important 
but ancillary; easily understood information such as the seasonal incidence of the smog, the likely duration of the most severe smog episodes at particular times of the year and the regional spread of the smog are all important. Such information can redirect tourists to other months of the year or encourage flexible itineraries. International tourist trips to China are typically spread over more than two to three days, and the prognosis for good days and severe stretches of smog can be useful for adjusting what to do and when to do it. In several destinations, proactive tourism industry responses to inclement weather which limits desired behaviours are offered (Baum \& Lundtrop, 2001). A sequence of three rainy days on tropical islands in Australia qualifies guests to a partial refund for their visit (Tourism Whitsundays, 2015). In other destinations affected by severe storms and extreme heat, daily itineraries are offered, which suggest ways for tourists to spend their time in less challenging places and pursuits (Pearce, 2005). Smog in Beijing and in many other attractive Chinese cities is a stark reality. The attractions of China do however excite global interest, and a positive profile of advice for tourists to cope with smog is a necessary accompaniment to the continued promotion of many unique and beautiful resources in Beijing and beyond. Some may argue that reducing tourism may in fact reduce smog. The argument is not trivial, but there is a counter view that the very pressure of seeking to be a key international destination, and an attractive one, brings strong pressure on civic and government authorities to address the fundamental drivers producing the undesirable smog disasters.

Unfortunately, the smog conditions in Beijing are likely to persist for several years. It also appears that media stories on the Beijing air pollution are accumulating steadily. At the same time, the Beijing government wants to achieve the status of having a world-class city. These two images of Beijing are undoubtedly in conflict and need to be resolved. From direct observation, the Beijing Municipal Commission in Tourism has at least publicly not engaged in any actions to address the smog issue. Does this mean the city's tourism will go 'up in smoke' too? This is hardly likely, given the past experiences of cities such as Los Angeles and London. However, it can be argued that a destination management organization (DMO) has a duty to take steps to protect the health and safety of its tourists, even if the presence of these steps discourage the more concerned and risk-averse visitors. It is strongly recommended that the Beijing tourism authority take action to better inform tourists of smog conditions and to warn people of the dangers of exposure to this air pollution.

\section{REFERENCES}

Akama JS, Kieti DM. 2003. Measuring Tourist Satisfaction With Kenya's Wildlife Safari: A Case Study of Tsavo West National Park. Tourism Management 24(1): 73-81.

Babin BJ, Chebat JC, Michon R. 2004. Perceived Appropriateness and its Effect on Quality, Affect and Behavior. Journal of Retailing and Consumer Services 11(5): 287-298.
Baldassare M, Katz C. 1992. The Personal Threat of Environmental Problems as Predictor of Environmental Practices. Environment and Behavior 24(5): 602-616.

Baum T, Lundtorp S. (eds). 2001. Seasonality in Tourism. Pergamon: Oxford.

Bickerstaff K. 2004. Risk Perception Research: Socio-Cultural Perspectives on the Public Experience of Air Pollution. Environment International 30(6): 827-840.

Bickerstaff K, Walker G. 1999. Clearing the Smog? Public Responses to Air-Quality Information. Local Environment 4(3): 279-294.

Bickerstaff K, Walker G. 2001. Public Understandings of Air Pollution: The 'Localisation' of Environmental Risk. Global Environmental Change 11(2): 133-145.

Bickerstaff K, Walker G. 2003. The Place (s) of Matter: Matter out of Place-Public Understandings of Air Pollution. Progress in Human Geography 27(1): 45-67.

Bigné JE, Andreu L. 2004. Emotions in Segmentation: An Empirical Study. Annals of Tourism Research 31(3): 682-696.

Blake A, Sinclair MT. 2003. Tourism Crisis Management: US Response to September 11. Annals of Tourism Research 30(4): 813-832.

del Bosque IR, Martín HS. 2008. Tourist Satisfaction a Cognitive-Affective Model. Annals of Tourism Research 35(2): 551-573.

Browne MW, Cudeck R. 1993. Alternative ways of assessing model fit. In Testing Structural Equation Models Bollen BA, Long JS (eds). Newbury Park, SAGE: CA; 136-162.

Cao J, Chow JC, Lee FS, Watson JG. 2013. Evolution of PM2. 5 Measurements and Standards in the US and Future Perspectives for China. Aerosol and Air Quality Research 13(4): 1197-1211.

Carr N. 2001. An Exploratory Study of Gendered Differences in Young Tourists Perception of Danger Within London. Tourism Management 22(5): 565-570.

Cavlek N. 2002. Tour Operators and Destination Safety. Annals of Tourism Research 29(2): 478-496.

Chen JS, Gursoy D. 2001. An Investigation of Tourists' Destination Loyalty and Preferences. International Journal of Contemporary Hospitality Management 13(2): 79-85.

Cheng WL, Chen YS, Zhang J, Lyons TJ, Pai JL, Chang SH. 2007. Comparison of the Revised Air Quality Index with the PSI and AQI Indices. Science of the Total Environment 382(2): 191-198.

Choi S, Lehto XY, Morrison AM, Jang SS. 2012. Structure of Travel Planning Processes and Information Use Patterns. Journal of Travel Research, 51(1): 26-40.

Cox DF. 1967. Risk taking and information handling in consumer behavior. In Risk Taking and Information Handling in Consumer Behavior. Harvard University: Boston; 604-639.

Crotts JC. 2004. The Effect of Cultural Distance on Overseas Travel Behaviors. Journal of Travel Research 43(1): 83-88.

Cupples J. 2009. Culture, Nature and Particulate Matter-Hybrid Reframings in Air Pollution Scholarship. Atmospheric Environment 43(1): 207-217.

Dolnicar S. 2005. Understanding Barriers to Leisure Travel: Tourist Fears as a Marketing Basis. Journal of Vacation Marketing 11(3): 197-208.

Dowling GR, Staelin R. 1994. A Model of Perceived Risk and Intended Risk-Handling Activity. Journal of Consumer Research 21(1): 119-134.

Eusébio C, Vieira AL. 2013. Destination attributes' Evaluation, Satisfaction and Behavioural Intentions: A Structural Modelling Approach. International Journal of Tourism Research 15(1): 66-80.

Evans GW, Jacobs SV, Frager NB. 1982. Human Adaptation to Smog. Journal of the Air Pollution Control Association 32(10): 1054-1057.

Fornell C, Larcker DF. 1981. Evaluating Structural Equation Models With Unobservable Variables and Measurement Error. Journal of Marketing Research 18(1): 39-50. 
Fransson N, Gärling T. 1999. Environmental Concern: Conceptual Definitions, Measurement Methods, and Research Findings. Journal of Environmental Psychology 19(4): 369-382.

Fuchs G, Reichel A. 2004. Cultural Differences in Tourist Destination Risk Perception: An Exploratory Study. Tourism (Zagreb) 52(1): 21-37.

Fuchs G, Reichel A. 2006. Correlates of destination risk perception and risk reduction strategies. In Progress in tourism marketing, Kozak M, Andreu L (eds). Elsevier: Amsterdam; 161-170.

Fuchs G, Reichel A. 2011. An Exploratory Inquiry into Destination Risk Perceptions and Risk Reduction Strategies of First Time vs. Repeat Visitors to a Highly Volatile Destination. Tourism Management 32(2): 266-276.

Genton B, D'Acremont V. 2012. Malaria Prevention in Travelers. Infectious Disease Clinics of North America 26(3): 637-654.

Goodrich JN. 2002. September 11, 2001 Attack on America: A Record of the Immediate Impacts and Reactions in the USA Travel and Tourism Industry. Tourism Management 23(6): 573-580.

Gore A. 2013. The Future. Random House: New York.

Hair JF, Tatham RL, Anderson RE, Black W. 2006. Multivariate Data Analysis Vol. 6. Pearson Prentice Hall: Upper Saddle River, NJ.

Hidalgo MC, Hernandez B. 2001. Place Attachment: Conceptual and Empirical Questions. Journal of Environmental Psychology 21(3): 273-281.

Hoelter JW. 1983. The Analysis of Covariance Structures Goodness-of-fit Indices. Sociological Methods \& Research 11(3): 325-344.

Hopper JR, Nielsen JM. 1991. Recycling as Altruistic Behavior Normative and Behavioral Strategies to Expand Participation in a Community Recycling Program. Environment and Behavior 23(2): 195-220.

Hu L, Bentler PM. 1995. Evaluating model fit. In Structural Equation Modelling: Concepts, Issues, and Applications Hoyle RH (eds). Sage: London.

Huan TC, Beaman J, Shelby L. 2004. No-Escape Natural Disaster: Mitigating Impacts on Tourism. Annals of Tourism Research 31(2): 255-273.

Huang Y, Scott N, Ding P, Cheng D. 2012. Impression of Liusanjie: Effect of Mood on Experience and Satisfaction. International Journal of Tourism Research 14(1): 91-102.

Hulme M. 2008. Geographical Work at the Boundaries of Climate Change. Transactions of the Institute of British Geographers 33(1): 5-11.

Hunter LM. 2000. A Comparison of the Environmental Attitudes, Concern, and Behaviors of Native-Born and Foreign-Born US Residents. Population and Environment 21(6): 565-580.

Ianniello A, Spataro F, Esposito G, Allegrini I, Hu M, Zhu T. 2011. Chemical Characteristics of Inorganic Ammonium Salts in PM 2.5 in the Atmosphere of Beijing (China). Atmospheric Chemistry and Physics 11(21): 10803-10822.

Jacoby LR. 1972. Perception of air, Noise and Water Pollution in Detroit. University of Michigan: New York, New York.

Jacoby J, Chestnut RW. 1978. Brand Loyalty Measurement and Management. Wiley: New York.

Jacquemin B, Sunyer J, Forsberg B, Götschi T, Bayer-Oglesby L, Ackermann-Liebrich U, Künzli N. 2007. Annoyance due to Air Pollution in Europe. International Journal of Epidemiology 36(4): 809-820.

Johnson BB. 2002. Gender and Race in Beliefs About Outdoor Air Pollution. Risk Analysis 22(4): 725-738.

Ko DW, Stewart WP. 2002. A Structural Equation Model of Residents' Attitudes for Tourism Development. Tourism Management 23(5): 521-530.

Kozak M, Rimmington M. 2000. Tourist Satisfaction With Mallorca, Spain, as an Off-Season Holiday Destination. Journal of Travel Research 38(3): 260-269.

Kozak M, Crotts JC, Law R. 2007. The Impact of the Perception of Risk on International Travellers. International Journal of Tourism Research 9(4): 233-242.
Law R. 2006. The Perceived Impact of Risks on Travel Decisions. International Journal of Tourism Research 8(4): 289-300.

Lepp A, Gibson H. 2003. Tourist Roles, Perceived Risk and International Tourism. Annals of Tourism Research 30(3): 606-624.

Lepp A, Gibson H, Lane C. 2011. Image and Perceived Risk: A Study of Uganda and its Official Tourism Website. Tourism Management 32(3): 675-684.

Liu B, Pennington-Gray L. 2015. Bed Bugs Bite the Hospitality Industry? A Framing Analysis of bed bug News Coverage. Tourism Management 48: 33-42.

Lopez-Valez R, Bayas JM. 2007. Spanish Travelers to High-Risk Areas in the Tropics: Airport Survey of Travel Health Knowledge, Attitudes, and Practices in Vaccination and Malaria Prevention. Journal of Travel Medicine 14(5): 297-305.

MacKenzie SB, Podsakoff PM, Podsakoff NP. 2011. Construct Measurement and Validation Procedures in MIS and Behavioral Research: Integrating New and Existing Techniques. MIS Quarterly 35(2): 293-334.

Mansfeld Y. 2006. The role of security information in tourism crisis management: The missing link. In Tourism, Security \& Safety Mansfeld Y, Pizam A (eds). Elsevier Butterworth-Heinemann: Amsterdam; 271-290.

Mao IY, Zhang HQ. 2012. Structural Relationships among Destination Preference, Satisfaction and Loyalty in Chinese Tourists to Australia. International Journal of Tourism Research 16(2): 201-208.

Mao CK, Ding CG, Lee HY. 2010. Post-SARS Tourist Arrival Recovery Patterns: An Analysis Based on a Catastrophe Theory. Tourism Management 31(6): 855-861.

McKercher B, Chon K. 2004. The Over-Reaction to SARS and the Collapse of Asian Tourism. Annals of Tourism Research 31(3): 716-719.

Moreira P. 2008. Stealth Risks and Catastrophic Risks: On Risk Perception and Crisis Recovery Strategies. Journal of Travel \& Tourism Marketing 23(2-4): 15-27.

Moutinho L. 2000. Strategic Management in Tourism. CABI: New York, NY; 96-98.

Noe FP. 1999. Tourism Service Satisfaction. Champaign, Illinois: Sagamore.

Nowacki MM. 2009. Quality of Visitor Attractions, Satisfaction, Benefits and Behavioural Intentions of Visitors: Verification of a Model. International Journal of Tourism Research 11(3): 297-309.

Nunkoo R, Ramkissoon H. 2011. Developing a Community Support Model for Tourism. Annals of Tourism Research 38(3): 964-988.

Nunnally JC, Bernstein IH. 1994. Psychometric Theory (3rd edn) McGraw-Hill: New York; 261-262

Oliver RL. 1997. Satisfaction: A Behavioral Perspective on the Consumer. McGraw-Hill: New York; 56-62.

Oppermann M. 2000. Tourism Destination Loyalty. Journal of Travel Research 39(1): 78-84.

Page S, Song H, Wu DC. 2012. Assessing the Impacts of the Global Economic Crisis and Swine Flu on Inbound Tourism Demand in the United Kingdom. Journal of Travel Research 51(2): 142-153.

Pearce PL. 2005. Tourist Behaviour: Themes and Conceptual Schemes. Clevedon: Channel View.

Pearce PL. 2011. Tourist Behaviour and the Contemporary World. Bristol: Channel View.

Petrick JF. 2004. Are Loyal Visitors Desired Visitors? Tourism Management 25(4): 463-470.

Qian Z, Chapman RS, Hu W, Wei F, Korn LR, Zhang JJ. 2004 Using air Pollution Based Community Clusters to Explore Air Pollution Health Effects in Children. Environment International 30(5): 611-620.

Qu H, Kim LH, Im HH. 2011. A Model of Destination Branding: Integrating the Concepts of the Branding and Destination Image. Tourism Management 32(3): 465-476.

Reichel A, Fuchs G, Uriely N. 2007. Perceived Risk and the nonInstitutionalized Tourist Role: The Case of Israeli Student exBackpackers. Journal of Travel Research 46(2): 217-226. 
Reisinger Y, Mavondo F. 2005. Travel Anxiety and Intentions to Travel Internationally: Implications of Travel Risk Perception. Journal of Travel Research 43(3): 212-225.

Richter LK. 2003. International Tourism and its Global Public Health Consequences. Journal of Travel Research 41: 340-347.

Rittichainuwat BN, Qu H, Mongknonwanit C. 2002. A Study of the Impact of Travel Satisfaction on the Likelihood of Travelers to Revisit Thailand. Journal of Travel \& Tourism Marketing 12(2/3): 19-43.

Roehl WS, Fesenmaier DR. 1992. Risk Perceptions and Pleasure Travel: An Exploratory Analysis. Journal of Travel Research 30(4): 17-26.

Rupp G. 2009. Aerosol Dynamics and Health: Strategies to Reduce Exposure and Harm. Biomarkers 14(S1): 3-4.

Ryan C. 1995. Researching Tourist Satisfaction: Issues, Concepts, Problems. Routledge: London.

Seddighi HR, Nuttall MW, Theocharous AL. 2001. Does Cultural Background of Tourists Influence the Destination Choice? An Empirical Study With Special Reference to Political Instability. Tourism Management 22(2): 181-191.

Semenza JC, Wilson DJ, Parra J, Bontempo BD, Hart M, Sailor DJ, George LA. 2008. Public Perception and Behavior Change in Relationship to hot Weather and Air Pollution. Environmental Research 107(3): 401-411.

Sharifpour M, Walters G, Ritchie BW, Winter C. 2014. Investigating the Role of Prior Knowledge in Tourist Decision Making: A Structural Equation Model of Risk Perceptions and Information Search. Journal of Travel Research 53(3): 307-322.

Simpson PM, Siguaw JA. 2008. Perceived Travel Risks: The Traveller Perspective and Manageability. International Journal of Tourism Research 10(4): 315-327.

Sjöberg L. 1989. Global Change and Human Action: Psychological Perspectives. International Social Science Journal 41: 413-432.

Sönmez SF, Graefe AR. 1998. Determining Future Travel Behavior from Past Travel Experience and Perceptions of Risk and Safety. Journal of Travel Research 37(2): 171-177.

Stern PC. 1992. Psychological Dimensions of Global Environmental Change. Annual Review of Psychology 43(1): 269-302.

Sudarmadi S, Suzuki, S, Kawada T, Netti, H, Soemantri S, Tugaswati AT. 2001. A Survey of Perception, Knowledge, Awareness, and Attitude in Regard to Environmental Problems in a Sample of two Different Social Groups in Jakarta, Indonesia. Environment, Development and Sustainability 3(2): 169-183.

Takala M. 1991. Environmental Awareness and Human Activity. International Journal of Psychology 26(5): 585-597.

Tan WK, Tang CY. 2013. Does Personality Predict Tourism Information Search and Feedback Behaviour?. Current Issues in Tourism 16(4): 388-406.

Tasci AD, Boylu Y. 2010. Cultural Comparison of Tourists' Safety Perception in Relation to Trip Satisfaction. International Journal of Tourism Research 12(2): 179-192.

Vitterso J, Vorkinn M, Vistad OI, Vagland J. 2000. Tourist Experiences and Attractions. Annals of Tourism Research 27(2): 432-450.

Wakefield SE, Elliott SJ, Cole DC, Eyles JD. 2001. Environmental Risk and (re) Action: Air Quality, Health, and Civic Involvement in an Urban Industrial Neighbourhood. Health \& Place 7(3): 163-177.

Wall G. 1973. Public Response to air Pollution in South Yorkshire, England. Environment and Behavior 5(2): 219-248.

Wang YS. 2009. The Impact of Crisis Events and Macroeconomic Activity on Taiwan's International Inbound Tourism Demand. Tourism Management 30(1): 75-82.

Wang M, Zhang R, Peng Y. 2001. Recent Researches on Aerosol in China. Advances in Atmospheric Sciences 18(4): 576-586.

Watts J. 2010. When a Billion Chinese Jump. Faber and Faber: London; 218.

Tourism Whitsundays. 2015. http://www.tourismwhitsundays.com. $\mathrm{au} /$ Accessed January 12, 2015

Wilks J, Page SJ. (eds). 2003. Managing Tourist Health and Safety. Oxford: Pergamon; 99

Williams AM, Baláž V. 2013. Tourism, Risk Tolerance and Competences: Travel Organization and Tourism Hazards. Tourism Management 35: 209-221.

Yoon Y, Uysal M. 2005. An Examination of the Effects of Motivation and Satisfaction on Destination Loyalty: A Structural Model. Tourism Management 26(1): 45-56.

Yüksel A, Yüksel F. 2007. Shopping Risk Perceptions: Effects on Tourists' Emotions, Satisfaction and Expressed Loyalty Intentions. Tourism Management 28(3): 703-713.

Zhang R, Wang M, Zhang X, Zhu G. 2003. Analysis on the Chemical and Physical Properties of Particles in a Dust Storm in Spring in Beijing. Powder Technology 137(1): 77-82. 